\title{
栄養素および食品群別摂取量推定のための食品群をベースとした 食物摂取頻度調查票の作成および妥当性
}

\author{
高 橋 啓 子*1, 吉 村 幸 雄*1, 開 元 多 恵*1, 國 井 大 輔*1, \\ 小松 龍 史*2, 山本 茂*2 \\ ${ }^{* 1}$ 四国大学生活科学部管理栄盖士養成課程, ${ }^{* 2}$ 徳島大学医学部栄養学科 \\ Validation of a Food Frequency Questionnaire Based on Food Groups for \\ Estimating Individual Nutrient Intake \\ Keiko Takahashi ${ }^{* 1}$, Yukio Yoshimura ${ }^{* 1}$, Tae Kaimoto ${ }^{* 1}$, Daisuke Kunii ${ }^{* 1}$, \\ Tatsushi Komatsu *2 and Shigeru Yamamoto*2 \\ ${ }^{* 1}$ Faculty of Human Life Science, Shikoku University ; \\ * 2 Department of Nutrition, School of Medicine, The University of Tokushima
}

A food frequency questionnaire (FFQg) was developed, based on 29 food groups and 10 kinds of cookery, for estimating the energy and nutrient intakes of an individual subject during the previous one to two months. This questionnaire was evaluated by a comparison with weighed dietary records for 7 continuous days (7d records) of 66 subjects aged 19-60 years.

The correlation coefficients between the FFQg and 7d records for energy, protein, fat, carbohydrate and calcium intakes were $0.47,0.42,0.39,0.49$ and 0.41 , respectively. The intakes of 26 of the 31 nutrients were not significantly different by paired $t$-tests between the two methods $(p \geqq 0.05)$. The ratio of the value obtained by the FFQg method against that by the $7 \mathrm{~d}$ records method ranged from $72 \% \quad$ (vitamin $\mathrm{B}_{12}$ ) to $121 \% \quad$ (vitamin $\mathrm{C}$ ). The average value of this ratio was $104 \%$.

The correlation coefficients for the intakes of rice, bread, meat, fish, milk, dairy products, green-yellow vegetables, other vegetables, and fruits were $0.66,0.76,0.27,0.27,0.72,0.58,0.46,0.53$, and 0.64 , respectively, between the FFQg and 7d records, and there was significant correlation between the two methods at the $p<0.05$ level for 22 of the 29 food groups.

Apart from those food groups for which "Less than once a month or never" was selected by $50 \%$ or more of the respondents. $34 \%$ of respondents could estimate portion sizes in the FFQg with an error of less than $25 \%$. The results show that the FFQg record is a useful instrument for estimating individual energy and nutrient intakes.

Jpn. J. Nutr., 59 (5) $221 \sim 232$ (2001)

\section{はじめに}

近年, 個人の健康状態や疾病に影響をおよほすをと考え られる長期間の食事摂取状況を推定する方法として, 食 事記録法や 24 時間思い出し法に代って食物捸取頻度調 查法がよく利用されるようになった。食物捸取頻度調查 法は, 食品リストにより設定された重量とその頻度を回 答する方法 ${ }^{11}$ で, 時間やコストがかからないという利 点がある。特定の食物や栄養素の摄取量を知ることを目 的に作成された食品リストによる調査は米国で開発さ れ, 食品や栄養素の搨取と疾病の関係を見出す疫学調査 で利用されている ${ }^{2 \sim 7}$ 。古野ら ${ }^{8)}$ は, がん研究への利
用を目的として，170項目の食品リストを用いて，その 搨取量と頻度を尋ねる方法を検討している。一方, 伊達 ら ${ }^{9)}$ は，食品リストの代りに122種類の料理（そのまま 食べる食品を含む）と過去 2 か月に 1 回以上捸取した料 理を聞き取る方法で，その妥当性を報告している。伊達 らは, 料理で質問することは, 食品への分解の必要がな いために, 調理に携わらない者にとっても有効な手段で あると述べている。

我が国では, 疫学調査ではなく健康増進の目的で個人 の栄養攝取状況を把握するために, 1981 年, 厚生省健 康指標策定委員会案による食物摄取状況調査票 ${ }^{10,11)}$ が

Key words : food frequency questionnaire, portion size, food group, cookery, nutrient intake, validity 食物摄取頻度調査票, ポーショシサイズ, 食品群, 調理, 栄養素攝取量, 妥当性

（連絡先：高橋啓子*1 ₹ 771-1192 徳島市応神町古川 電話 088-665-1300 内線 2227) 
作成された。この方法は，六つの基礎食品を基本に，そ れぞれの食品群の 1 回または 1 日の平均的な摂取量を回 答し，80kcal単位に換算して計算するものである。この 調査法をべースにして, さらに摄取頻度も加えて, 食品 群ごとに摄取量と頻度を尋ねる方法が種々開発されてき

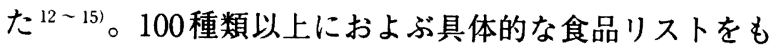
とに拱取量および摄取頻度について聞く方法に対して, これらの方法は, 多くても30種類程度の食品群にまと めて質問するのが大きな特徴である。食品群にまとめて 質問する方法では，それぞれの食品がどのような料理に 含まれるかを考え，食品群ごとに合計するということは， 料理に携わっていない人にとって甚だ困難であることは すでに指摘されている9)。しかしながら，料理を食品に 分解してそれぞれの食品群にまとめるという作業を介助 者の助けを借りて自ら行うことは，日常の食事を把握し て食生活を改善するという栄盖指導の目的には大変有効 で，この方法の利点でもあると考えられる。

そこで, 今回, 質問する食品群と食品群ごとのポーシ ヨンサイズおよび調理法を見直し，さらに食品イラスト
も利用して，日常の $1 \sim 2$ か月程度の期間の栄養素およ び食品群別摂取量を推定する方法，すなわち食品群によ る食物摄取頻度調查票（以下, FFQg という）を開発し， 1 週間の食事記録（以下，記録法という）と比較して有 用性を検討したので報告する。

\section{研 究 方 法}

1. 食物摄取頻度調査票（FFQg）の作成

（1） 食品群分類

FFQg 法では森本ら ${ }^{10)}$ が使用した食品群分類を参考 に, さらに細分化して 29 食品群とした。食品群の種類 については，第五次改定日本人の栄養所要量で示された 食品構成に再構成できる分類を採用し, 適正量を求めや すくした。

さらに，砂糖や食塩，油脂類の撖取量を推定するため に, ご飯もの, 煮物, 和え物, 揚げ物, 炒め物, 汁物な ど調理法の質問を設けた。これらの食品は調味料として 使用されていることが多く, 契食者にはそれがどの程度 使用されているか把握し難い。それゆえ，これらの食品

表 1 FFQg 法に用いた食品群別基準ポーションサイズ

\begin{tabular}{|c|c|c|c|c|c|}
\hline 食品群 & 重量 (g) & 備 考 & 食品群 & 重量 (g) & 備 考 \\
\hline 飯（米類） & 65 & 最頻値 & 和菓子 & 32 & 最頻値 \\
\hline パン類 & 60 & 常用量 & 菓子パンやケーキ & 93 & 常用量 \\
\hline 麺類（乾燥） & 75 & 常用量 & スナック・揚げ菓子 & 100 & 常用量 \\
\hline 和風飯もの (調味料) & 25 & 1 回当たりの平均値 & せんべい類やクッキー & 10 & 常用量 \\
\hline 洋風飯もの (調味料) & 35 & 1 回当たりの平均値 & アイスクリーム & 115 & 常用量 \\
\hline 缅類の汁 & $0.75,1.5,3$ & 1 食当たりの塩分量 & チョコレート & 45 & 包装単位 \\
\hline 肉 - 肉加工品類 & 80 & 主材料としての常用量 & キャンディ・キャラメル & 5 & 包装単位 \\
\hline 魚介類 & 80 & 主材料としての常用量 & ゼリーやプリン & 70 & 常用量 \\
\hline 小魚類 & 20 & 常用量 & 砂糖（飲み物用） & 6 & 包装単位 \\
\hline 卵類 & 50 & 1 個（個数単位） & その他の嗜好飲料 & $110,250,350$ & 常用サイズ \\
\hline 大豆・大豆製品（味増は除く & く) 70 & 常用量 & アルコール類 & 300 & ビール 1 本相当量 \\
\hline 牛乳 & 170 & コップ1杯 & 栄養補助食品 & 50 & 常用量 \\
\hline その他の乳製品 & 62.5 & $\begin{array}{l}\text { 常用量 } 100 \mathrm{~g} \text { からカル } \\
\text { シウム量により換算 }\end{array}$ & $\begin{array}{l}\text { バター・マーガリン } \\
\text { 天ぷらやフライ（油） }\end{array}$ & $\begin{array}{r}4 \\
10\end{array}$ & $\begin{array}{l}\text { 最頻値 } \\
1 \text { 回当たりの平均値 }\end{array}$ \\
\hline 海草類 & 4 & $\begin{array}{l}\text { 海草使用料理の } 1 \text { 回 } \\
\text { 平均値 }\end{array}$ & $\begin{array}{l}\text { マヨネーズやドレッシング } \\
\text { 炒め物 (油) }\end{array}$ & $\begin{array}{r}12 \\
5\end{array}$ & $\begin{array}{l}1 \text { 回当たりの平均値 } \\
1 \text { 回当たりの平均値 }\end{array}$ \\
\hline 緑黄色野菜 & 50 & 1 回当たりの平均値 & " (塩分) & 0.5 & 1 回当たりの平均値 \\
\hline その他の野菜・きのこ類 & 80 & 1 回当たりの平均値 & 種実類（ゴマ以外） & 15 & 常用量 \\
\hline 果物 & 150 & 最頻値 & " (ゴマ) & 2 & 最頻値 \\
\hline いも類 & 100 & 常用量 & 梅干し・佃者類 & 10 & 常用量 \\
\hline ジャム・ハチミツ類 & 7 & 最頻値 & 漬け物類 & 30 & 常用量 \\
\hline 煮物料理（砂糖） & 10 & 1 回当たりの平均値 & 調味料（しょうゆ・ソース） & 7 & 常用量 \\
\hline （塩分） & 3 & 1 回当たりの平均値 & 味噌汁 & 12 & 平均値 \\
\hline $\begin{array}{cc}\text { 酢の物や和え物（砂糖）} \\
" \text { (塩分) }\end{array}$ & $\begin{array}{l}3 \\
1\end{array}$ & $\begin{array}{l}1 \text { 回当たりの平均値 } \\
1 \text { 回当たりの平均値 }\end{array}$ & $\begin{array}{l}\text { その他の汁 } \\
\text { 外食の味の感じ於よる食醏ファクター }\end{array}$ & $\begin{array}{c}1.2 \\
1.3,1.15,1\end{array}$ & 1 食当たりの塩分量 \\
\hline
\end{tabular}

注） 1 回当たりの平均値は搷取した人のみから計算した。 
表 2 外食の味の感じ方と味噌汁の塩分濃度

$(n=170)$

\begin{tabular}{|c|c|c|c|c|}
\hline 選択カテゴリー & 人数 & 平均 $(\%)$ & 土標準偏差 & $t$-検定 \\
\hline 1. 家庭の味より外食の味を薄く感じる & 24 & 0.94 & \pm 0.25 & \\
\hline 2. 家庭と外食の味はほとんど同じ & 54 & 0.83 & \pm 0.19 & $* * *$ \\
\hline 3. 家庭の味より外食の味を濃く感じる & 92 & 0.74 & \pm 0.21 & \\
\hline
\end{tabular}

注) * $p<0.05,{ }^{* * *} p<0.001$ (両側)

平均塩分浱度は「1. 家庭の味より外食の味を薄く感じる」は「3．家庭の味より外食の味を漛く感じる」の 1.27 倍, 「2. 家庭 と外食の味はほとんど同じ」は「3．家庭の味より外食の味を浱く感じる」の1.11倍であった。

については，砂糖や塩分，油脂を多く含有する食品以外 に,どのような調理法で料理を食べるかという観点から も計算できるようにした。砂糖，食塩の摂取量の推定に はご飯ものや煮物, 和え物, 汁物などについて7 項目, 油脂類の摃取量の推定については揚げ物や炒め物， マヨ ネーズ類の使用について3項目の質問を設けた。

質問の順序についても主食, 主菜となる順とし, 被調 查者が思い出しやすいことに配虑した。また，食品群ご との食品を，イラストで分量の概念を入れて例示した。 さらに摄取分量が把握しやすいように，食品ごとの主な 調理法と目安量を示した。調查時間は, 予備調査におい て対面形式をとった場合で15２0分程度であった。

（2）ポーションサイズの決定と食塩ファクター

食品群ごとの 1 回当たり摂取量（ポーションサイズ） の基準量を表 1 の通り決定した。ポーションサイズの基 準量は1997年に徳島県において実施された県民健康 ・ 栄養調查 ${ }^{16)}$ データから各食品群ごとに，主な調理法に よる平均值または最頻値を求め, 1 回当たり摄取量とし た。多種類の調理法にわたる食品については，常用量を 採用した。

また，各家庭の味付けについて，外食料理の味と比較 した質問を設けた。食塩の計算時にこれをファクター化 し，乗じることとした。このファクターは，1998年実 施の徳島県穴吹町農業従事者の栄盖調查 ${ }^{17)}$ 時に測定し た各家庭の味噌汁の塩分濃度と FFQg 法の選択カテゴリ 一から求めた。FFQg 法による栄養調査時に各家庭から 持参した味噌汁の塩分濃度を測定し, FFQgの質問にあ る外食の味の感じ方による選択カテゴリー別に味噌汁の 平均塩分濃度を計算すると, 表 2 の通り,「1．家庭の 味より外食の味が薄い」と回答した者の塩分濃度は $0.94 \%$,「2．家庭と外食の味はほとんど同じ」者 $0.83 \%$,「 3 ．家庭の味より外食の味が濃い」者 $0.74 \%$ で，塩分港度に差がみられた。味噌汁は日常摂取される 料理であることから，各家庭の味付けの傾向を示すもの と考えられる。そこで, 味噌汁の平均塩分濃度から, 外 食料理の味の感じ方で選択カテゴリー「1，家庭の味よ り外食の味を薄く感じる」を回答した者は, 選択カテゴ
リー「3．家庭の味より外食の味を濃く感じる」を回答 した者の 1.3 倍,「2．家庭と外食の味はほとんど同じ」 を回答した者は「3．家庭の味より外食の味を濃く感じ る」の 1.15 倍として, 料理の捺取回数から食塩量を計算 する質問項目にここのファクターを乗じることとした。

（3）カテゴリー分類と頻度

ポーションサイズの重量カテゴリーを 3 段階設け, 「少し」は「普通」の半分,「たっぷり」は「普通」の 1.5 倍とした。なお， 1 か月に $1 \sim 2$ 回程度以下の頻度 で摄取する場合は「食べない」を選択することとした。

頻度の回答は, 朝・昼・夕食ごとに過去 $1 \sim 2$ か月間 における 1 週間の平均的な摄取回数を回答することと し,重量カテゴリーでその分量に当てはまらない場合は, 1 週間の回数で調整するように回答時に指示することと した。摄取頻度が少ないと思われる食品群については， 1 回量と 1 週間の回数を回答することとした。飯（茶碗 1 杯), 牛乳 (コップ1杯), 卵など重量の把握しやすい 食品については 1 週間の頻度 (回数)のみを回答させた。

(4) 調査票の記入

調査は自記式とし, 専門知識を有する者がそれを介助 する形を基本にした。よって, 設問内容や食品の概量が 一般の人々にも把握しやすいように図式化した。これに より文字だけの表現より, 食品の種類や概量がわかりや すく，回答しやすくなった。なお，質問用紙（資料）に ついては一部を揭載したが, FFQgおよび計算に使用し た荷重平均成分表等は提供することができる。

（5）栄盖素摄取量等の算出

FFQg 法の栄養計算に用いる食品成分表は, 1997 年徳 島県県民健康 - 栄盖調査 ${ }^{16}$ 加荷重平均成分表を作成 し, エネルギー, 三大栄盖素, 微量栄盖素拈よび脂肪酸 攝取量の計算が可能な成分表を作成した。FFQg 法によ る 1 日当たり栄養素攝取量は, 食品群ごとに次式により 求めた上で合計した。

栄養素撕取量 $=$ 食品群ごとのポーションサイズ （g） × 重量カテゴリー ${ }^{\sharp} \times$ 撕取回数 $/ 7 \times$ 荷重 平均成分表の食品群 $100 \mathrm{~g}$ 当たりの各栄養素 量/100 
資料 食物摄取頻度調查票 $(F F Q g)$ の一部 $(1 / 4$ ページ $)$

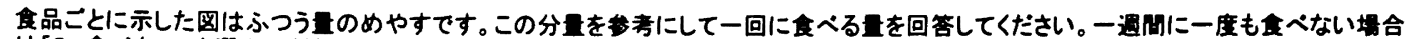

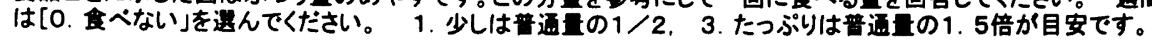

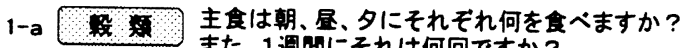
また、1週咸にそれは何回ですか？

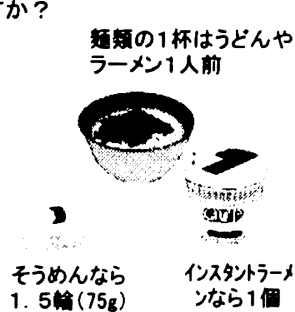

ーb お毒司や炊き込みこ販、どんぶりなど和風のこ眅ものは1週間に何回食べますか?

-c かレーライスやハヤシライス、グラタンなどルーを使った料理は1週間に何回食へます か?

2 肉加工品頛 肉や肉の加工品はどのくらい食べますか?

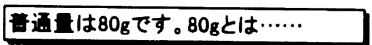
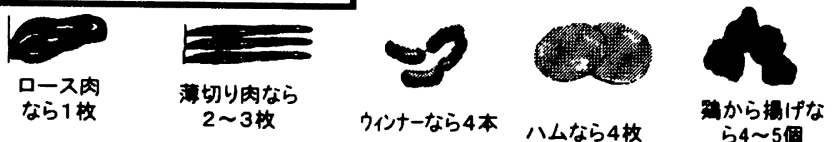

3

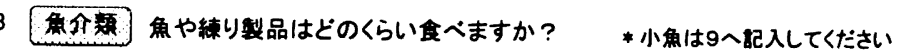

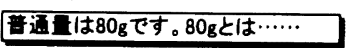

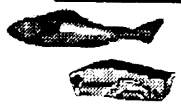

なら中 1 廉

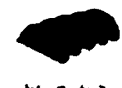

さしみなら
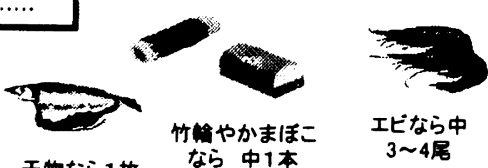

竹やかまほこエエビなら中

また1切れ

干物なら1板

なら 中1本

畉は1週用に何個くらい食べますか?

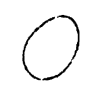

1㑭は触卵1佃

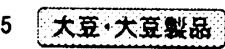

大豆・大豆製品はどのくらい食べますか?

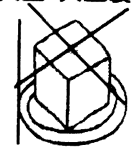

*味叶汁の豆度なら「1少 し」を通んでくたさい

豆鹿なら $1 / 47$

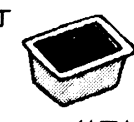

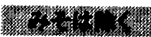

\section{4乳・乳幣昆

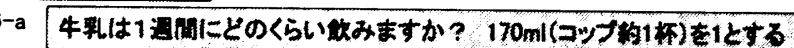

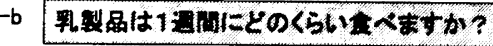

$$
\begin{aligned}
& \text { ヨーグルト(加榼)な } \\
& \text { ら1㑑 }(100 \mathrm{~g})
\end{aligned}
$$

7 海泟 ワカメやUじきなどの海草はどのくらい食べますか?
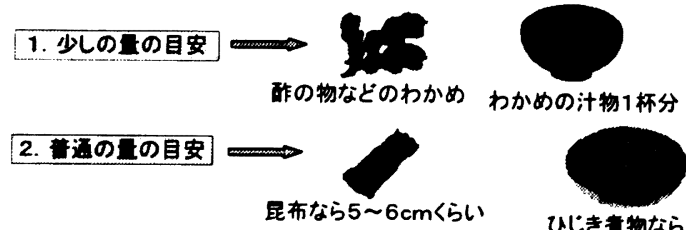

ひじき事物なら小如 1 杯
回 管相

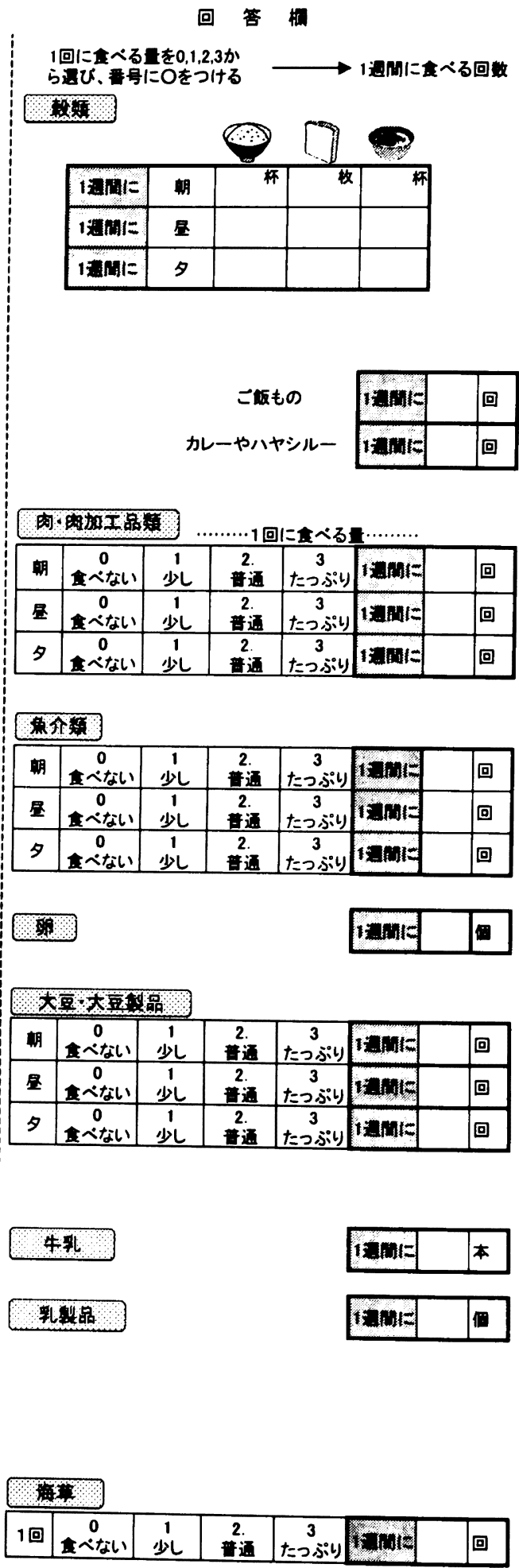


\#重量カテコリリー別（「食べない」＝0，「少 し」 $=0.5$,「普通」=1,「たっぷり」=1.5) の倍数を乗じる。重量カテコリリーのない質 問はこの項を省く。

食品群別摄取量は, 食品群ごとのポーションサイ ス $(\mathrm{g}) \times$ 重量カテコリー\#×摂取回数 $/ 7$ で 算出した。

2. 食物攝取頻度調查票（FFQg）を用いた調査の再 現性と妥当性

（1）対象および調查期間

FFQg 法による推定摄取量の妥当性を検討するため に，7日間記録法を実施して対照とした。両調査は食物 栄養専攻学生（19歳）53名，およびその父母など協力 を得られた成人 13 名 (40歳代 8 名, 60 歳代 5 名), 合計 66名について実施した。そのうち男性は学生 2 名，40歳 代1名の計3名である。

記録法の調查期間は 1999 年 1〜3月の連続した 7 日間 である。FFQgは食事記録を実施した後， 2 週間程度経 過してから食事記録を実施した 1 週間を含む過去 1 か月 間の食事を対象に,平均的な 1 週間について回答させた。 Jain ら”が30日間の食事記録と食歴法を比較検討した 結果, その内の 1 週間の食事と食歷との間に相関があっ たことを報告していることから，食事記録は 1 週間とし た。なお，学生の中で19名については食事記録を実施 する前にも FFQgを行い， 1 か月以上の期間を置いて 2 度FFQg を実施し，再現性の検討を行った。

(2) FFQg 法と記録法の栄盖素および食品群別撖取 量の比較

記録法による食品の摂取量については秤量を基本にし て記録してもらったが，外食や市販栔菜などその素材の 不明なものについては概量から重量を求めた。また，油 脂類や調味料などで秤量できなかったものについては, 調味パーセント ${ }^{18}$ から調味料ごとの重量を求めた。

記録法の栄盖計算にはExcelアドインソフト，エクセ ル栄養君 ${ }^{19)}$ を用いた。四訂日本食品標準成分表および 五訂日本食品標準成分表一新規食品編一に収載されてい ない食品は類似食品で代替した。しかし，適当な代替食 品がない場合や市販食品については市販食品成分表 ${ }^{20}$ により計算した。また，一部の食品にしか記載のないコ レステロールや食物阵維についてはエクセル栄養君に示 されている代替食品の值により計算した。代替食品が当 てはまらない栄盖素は「0」として計算した。栄養素お よび食品群別摄取量の両調查法間の差の検定は, paired $t$-検定を用いた。相関係数は Pearsonの方法で求めた。 さらに，両調査法間の栄養素および食品群別摄取量の平 均値の比 (FFQg 法/記録法) を求め, FFQg 法による 撕取量推定と記録法による摂取量の差を検討した。デー
夕の解析にはSPSS ${ }^{21)}$ を用いた。

（3） FFQg 法に設定したポーションサイズと記録法 による 1 回当たり推定摄取量の比較

$\mathrm{FFQg}$ では 1 週間の平均的な摂取量を食品群ごとの 1 回当たり摄取量であるポーションサイズと 1 週間の回数 について回答する。よって，重量カテゴリーと回数を回 答する食品群についてのみ，記録法による 1 週間の総搨 取量を FFQg 法で回答された回数で除して，回答者の 1 回当たり推定摄取量を求め, FFQgの重量カテゴリー （ポーションサイズ）を正しく推定して選択されたかど うかを検討した。椇取回数については，漬け物，嗜好飲 料で記録法による回数と FFQg 法の回数の比が $0.6,2.2$ と大きかった。しかし，その他の食品については $0.8 か$ ら 1.2 倍の範囲で平均 0.99 と大きな差は見られなかった ため, 記録法と FFQg 法の攝取回数を同じと仮定した。 記録法の攝取回数を用いなかったのは，摂取時の食品の 状態により，重量が大きく変動するためである。

推定された 1 回当たり摂取量が FFQgの重量カテゴリ 一の設定重量 $\pm 25 \%$ 以内の者を適正回答とし，適正回 答率を求めた（適正回答率 $(\%)=\mathrm{FFQg}$ 法で重量カテ ゴリー「0．ほとんど食べない」，「1，少し」，「2．普 通」,「3．たっぷり」のいずれかを選択し，かつ，記録 法による 1 回推定摄取量がFFQgのそれぞれの重量カテ ゴリーの設定重量 $\pm 25 \%$ 以内'の延べ [朝・昼・夕食の 合計] 人数/FFQg の回答延べ人数 $\times 100,1$ 回当たり推 定摄取量 = 記録法による 1 週間の総摄取量 $/ F F Q g$ の摄 取回数。'「0。ほとんど食べない」を回答した者は記 録法による搷取量が 0 「「1，少し」を回答した者は記 録法の 1 回推定摄取量が基準ポーションサイズの$26 \%$ 以下,「2．普通」を回答した者は記録法の 1 回推 定摄取量が基準ポーションサイズのー 25\%〜+25\%以 下，「3．たっぷり」を回答した者は記録法の 1 回推定 損取量が基準ポーションサイズの+ $26 \%$ 以上の範囲と した)。

さらに, FFQgにおいて「2。普通」を選択した者の 記録法の 1 回当たり推定椇取量とポーションサイズにつ いて検討した。ただし，FFQgで「0．ほとんど食べな い」を選択した延へ人数が $50 \%$ 以上の食品群は省いた。

\section{結果}

1. FFQgの再現性

FFQg 食事記録の前後に実施した19名については, 前・後の間でエネルギーおよび栄養素摄取量の相関係数 を求めた（表 3$)$ 。エネルギー（0.54），たんぱく質 $(0.53)$, 脂質 $(0.63)$, 炭水化物 $(0.49)$, カルシウム $(0.63)$, リン $(0.54)$, 鉄 $(0.54)$, レチノール $(0.78)$, ビタミン B 1 (0.49), ビタミン B $2(0.60)$, コレステロ 
表 3 記録法の前後に実施された 2 回の FFQg 法の栄養素および食品群別摂取量（1日当たり）

$(n=19)$

\begin{tabular}{|c|c|c|c|c|}
\hline \multirow{2}{*}{ 栄盖素/食品群 } & FFQg 法 1 回目 & FFQg 法 2 回目 & \multirow{2}{*}{ 相関係数 } & \multirow{2}{*}{$\begin{array}{l}1 \text { 回目/ } \\
2 \text { 回目 }(\%)\end{array}$} \\
\hline & 平均値 \pm 標準偏差 & 平均値 \pm 標準偏差 & & \\
\hline \multicolumn{5}{|l|}{ 栄養素 } \\
\hline エネルギー（kcal） & $1,452 \pm 359$ & $1,350 \pm 326$ & $0.540^{*}$ & 107.6 \\
\hline たんぱく質（g） & $51.6 \pm 11.8$ & $49.6 \pm 13.6$ & $0.529^{*}$ & 104.2 \\
\hline 脂質（g） & $46.2 \pm 17.0$ & $43.7 \pm 13.3$ & $0.626^{* *}$ & 105.7 \\
\hline 炭水化物（g） & $204.6 \pm 47.5$ & $187.0 \pm 43.5$ & $0.486^{*}$ & 109.4 \\
\hline カルシウム（mg） & $376 \pm 119$ & $366 \pm 140$ & $0.633^{* *}$ & 102.7 \\
\hline リン（mg） & $773 \pm 158$ & $746 \pm 193$ & $0.543^{*}$ & 103.7 \\
\hline 鉄（mg） & $7.3 \pm 2.0$ & $6.9 \pm 2.0$ & $0.535^{*}$ & 105.6 \\
\hline カリウム（mg） & $1,782 \pm 448$ & $1,696 \pm 481$ & 0.344 & 105.1 \\
\hline レチノール（ $(\mu \mathrm{g})$ & $173 \pm 47$ & $186 \pm 60$ & $0.781^{* * *}$ & 92.9 \\
\hline ビタミン A 効力 (IU) & $1,974 \pm 676$ & $1,859 \pm 794$ & 0.340 & 106.1 \\
\hline ビタミン $\mathrm{B}_{1} \quad(\mathrm{mg})$ & $0.73 \pm 0.15$ & $0.73 \pm 0.19$ & $0.486^{*}$ & 101.0 \\
\hline ビタミン $\mathrm{B}_{2}(\mathrm{mg})$ & $0.87 \pm 0.19$ & $0.88 \pm 0.24$ & $0.602^{* *}$ & 99.3 \\
\hline ナイアシン（mg） & $10.6 \pm 2.3$ & $10.4 \pm 2.9$ & 0.322 & 102.5 \\
\hline ビタミンC（mg） & $83 \pm 32$ & $81 \pm 36$ & 0.179 & 102.2 \\
\hline ビタミン D（IU） & $134 \pm 67$ & $112 \pm 67$ & 0.278 & 119.9 \\
\hline ビタミンE（mg） & $5.2 \pm 1.5$ & $4.6 \pm 1.3$ & 0.413 & 111.7 \\
\hline 食塩相当量（g） & $7.6 \pm 3.0$ & $6.5 \pm 2.4$ & 0.429 & 116.6 \\
\hline コレステロール（mg） & $258 \pm 68$ & $272 \pm 78$ & $0.723^{* * *}$ & 94.8 \\
\hline 食物織維（g） & $9.0 \pm 3.1$ & $8.5 \pm 3.0$ & 0.379 & 106.4 \\
\hline \multicolumn{5}{|l|}{ 食品群（g） } \\
\hline 米類 & $118.3 \pm 30.8$ & $112.7 \pm 33.3$ & $0.524^{*}$ & 105.0 \\
\hline パン類 & $30.2 \pm 28.3$ & $31.6 \pm 20.6$ & $0.714^{* * *}$ & 95.7 \\
\hline 麺類 & $22.6 \pm 18.2$ & $13.5 \pm 17.8$ & $0.522^{*}$ & 166.7 \\
\hline 肉·肉加工品類 & $60.2 \pm 20.3$ & $68.9 \pm 30.1$ & $0.485^{*}$ & 87.3 \\
\hline 魚介類 & $44.5 \pm 25.9$ & $34.6 \pm 25.9$ & 0.198 & 128.7 \\
\hline 卵類 & $31.6 \pm 12.2$ & $35.7 \pm 11.2$ & $0.686^{* *}$ & 88.4 \\
\hline 大豆・大豆製品 （味噌は除く） & $32.9 \pm 20.8$ & $27.9 \pm 27.4$ & $0.630^{* *}$ & 117.9 \\
\hline 牛乳 & $53.7 \pm 54.7$ & $59.6 \pm 62.7$ & $0.889^{* * *}$ & 90.1 \\
\hline その他の乳製品 & $19.9 \pm 18.8$ & $22.6 \pm 21.1$ & $0.540^{*}$ & 88.1 \\
\hline 海草類 & $1.1 \pm 0.6$ & $1.0 \pm 0.8$ & 0.315 & 110.9 \\
\hline 小魚類 & $1.0 \pm 1.6$ & $0.8 \pm 1.4$ & $0.494^{*}$ & 118.2 \\
\hline 緑黄色野菜 & $56.0 \pm 28.9$ & $48.5 \pm 30.7$ & 0.327 & 115.5 \\
\hline その他の野菜・きのこ類 & $106.4 \pm 70.1$ & $112.4 \pm 66.6$ & 0.348 & 94.6 \\
\hline 果物 & $59.8 \pm 43.6$ & $55.3 \pm 48.1$ & 0.265 & 108.2 \\
\hline いも類 & $20.7 \pm 17.3$ & $27.4 \pm 18.0$ & 0.433 & 75.3 \\
\hline ジャム・ハチミツ類 & $0.3 \pm 1.0$ & $0.3 \pm 0.7$ & 0.047 & 95.8 \\
\hline 菓子類（合計） & $83.5 \pm 63.0$ & $60.6 \pm 37.9$ & 0.445 & 137.8 \\
\hline 砂糖 & $4.2 \pm 2.3$ & $4.3 \pm 2.8$ & $0.631^{* *}$ & 97.1 \\
\hline その他の嗜好飲料 & $47.7 \pm 64.4$ & $60.1 \pm 77.5$ & $0.614^{* *}$ & 79.3 \\
\hline 油脂類 & $5.6 \pm 4.4$ & $5.3 \pm 3.1$ & $0.670^{* *}$ & 107.1 \\
\hline マヨネーズ・ドレッシング類 & $4.7 \pm 3.2$ & $4.9 \pm 2.9$ & 0.303 & 96.3 \\
\hline バター・マーガリン & $0.8 \pm 0.7$ & $1.1 \pm 1.1$ & 0.153 & 71.2 \\
\hline 種実類 & $0.1 \pm 0.3$ & $0.3 \pm 0.7$ & 0.128 & 40.0 \\
\hline 種実類（ゴマ） & $0.2 \pm 0.2$ & $0.4 \pm 0.8$ & 0.302 & 44.3 \\
\hline 梅干し・佃煮類 & $1.6 \pm 1.7$ & $0.6 \pm 0.8$ & -0.101 & 265.6 \\
\hline 漬け物類 & $7.3 \pm 11.0$ & $5.8 \pm 9.3$ & 0.059 & 127.5 \\
\hline 調味料類（しょうゆ・ソース類） & $4.7 \pm 4.7$ & $4.1 \pm 2.7$ & $0.476^{*}$ & 114.8 \\
\hline 味噌 & $6.0 \pm 4.5$ & $5.3 \pm 4.3$ & $0.728^{* * *}$ & 113.6 \\
\hline
\end{tabular}

注) ${ }^{*} p<0.05,{ }^{* *} p<0.01,{ }^{* * *} p<0.001$

FFQg 法 1 回目は記録法実施の前，2回目は後に実施した。

アルコール類の摄取はなかったため省いた。 
ール（0.72）については $p<0.05$ の相関が得られ, 食品群 別摄取量についても米類 $(0.52)$, パン類 $(0.71)$, 麺類 (0.52), 卵類 $(0.69)$, 大豆・大豆製品 $(0.63)$, 牛乳 (0.89), その他の乳製品 $(0.54)$, 砂糖 $(0.63)$, その他 の嗜好飲料 (0.61), 油脂類 (0.67), 味噌 (0.73) で 0.5 以上の相関が得られた。また, 記録法の前 (FFQg 1 回 目) と後 (FFQg 2 回目) の栄養素攝取量の平均値の比 は, 19 栄養素中 16 種類で $90 〜 110 \%$ 範囲であった。

\section{FFQg法と記録法による栄養素捸取量の比較}

両調査法による平均栄養素摄取量を比較すると（表 $4)$ ，エネルギー，たんぱく質，脂質，炭水化物など主 栄養素はFFQg 法がやや高値であった。平均摄取量の FFQg 法と記録法の比はエネルギー106\%，たんぱく質 $103 \%$ ，脂質 $108 \% ，$ 炭水化物 103\%，カルシウム $105 \%$ であり，やや過大評価された。一方，鉄 $(89 \%)$, ビ夕 ミンD $(87 \%)$ の攝取量は少なく見積もられた。31栄 養素中 19 種類の栄養素については, FFQg 法と記録法

表4 FFQg 法と記録法による栄盖素摂取量（1日平均）の比較

\begin{tabular}{|c|c|c|c|c|c|}
\hline \multirow{2}{*}{ 栄養素 } & FFQg 法 & 記録法 & \multirow{2}{*}{ 相関係数 } & \multirow{2}{*}{$\begin{array}{c}\text { paired } t \text {-検定 } \\
p \text { 値 (両側) }\end{array}$} & \multirow{2}{*}{$\begin{array}{l}\text { FFQg 法/ } \\
\text { 記録法(\%) }\end{array}$} \\
\hline & 平均値 士標準偏差 & 平均値士標準偏差 & & & \\
\hline エネルギー（kcal） & $1,666 \pm 556$ & $1,568 \pm 347$ & $0.465^{* * *}$ & 0.116 & 106.2 \\
\hline たんぱく質（g） & $60.2 \pm 23.5$ & $58.3 \pm 13.7$ & $0.416^{* * *}$ & 0.471 & 103.3 \\
\hline 脂質（g） & $52.2 \pm 22.6$ & $48.1 \pm 15.5$ & $0.387^{* *}$ & 0.134 & 108.5 \\
\hline 炭水化物（g） & $234.2 \pm 73.0$ & $226.4 \pm 52.3$ & $0.488^{* * *}$ & 0.341 & 103.4 \\
\hline カルシウム（mg） & $452 \pm 193$ & $430 \pm 171$ & $0.410^{* * *}$ & 0.381 & 105.0 \\
\hline リン（mg） & $911 \pm 325$ & $871 \pm 217$ & $0.454^{* * *}$ & 0.280 & 104.6 \\
\hline 鉄 $(\mathrm{mg})$ & $8.2 \pm 3.2$ & $9.2 \pm 5.4$ & -0.014 & 0.180 & 88.7 \\
\hline カリウム (mg) & $2.003 \pm 731$ & $1,945 \pm 670$ & 0.229 & 0.587 & 103.0 \\
\hline レチノール（ $\mu \mathrm{g})$ & $212 \pm 93$ & $189 \pm 133$ & 0.177 & 0.218 & 112.0 \\
\hline ビタミン A 効力 (IU) & $2,008 \pm 932$ & $1,922 \pm 1,185$ & 0.059 & 0.637 & 104.4 \\
\hline ビタミン $\mathrm{B}_{1} \quad(\mathrm{mg})$ & $0.85 \pm 0.31$ & $0.77 \pm 0.22$ & $0.403^{* * *}$ & 0.041 & 110.0 \\
\hline ビタミン $\mathrm{B}_{2} \quad(\mathrm{mg})$ & $1.02 \pm 0.38$ & $1.03 \pm 0.32$ & $0.416^{* * *}$ & 0.820 & 99.0 \\
\hline ナイアシン (mg) & $12.2 \pm 4.8$ & $11.6 \pm 3.4$ & $0.244^{*}$ & 0.382 & 104.8 \\
\hline ビタミンC（mg） & $88 \pm 47$ & $73 \pm 43$ & $0.479^{* * *}$ & 0.009 & 120.8 \\
\hline ビタミンD（IU） & $140 \pm 91$ & $162 \pm 161$ & 0.030 & 0.339 & 86.6 \\
\hline ビタミン E (mg) & $5.5 \pm 2.0$ & $5.6 \pm 4.9$ & 0.129 & 0.825 & 97.6 \\
\hline 食塩相当量（g） & $8.3 \pm 3.7$ & $8.5 \pm 3.5$ & $0.426^{* * *}$ & 0.549 & 96.7 \\
\hline コレステロール（mg） & $310 \pm 142$ & $294 \pm 112$ & $0.517^{* * *}$ & 0.316 & 105.4 \\
\hline 食物䋮維（g） & $10.0 \pm 3.7$ & $9.5 \pm 3.6$ & $0.435^{* * *}$ & 0.325 & 105.0 \\
\hline ビタミン K $(\mu \mathrm{g})$ & $209 \pm 105$ & $235 \pm 162$ & 0.164 & 0.230 & 88.7 \\
\hline ビタミン B6（mg） & $0.84 \pm 0.31$ & $0.76 \pm 0.26$ & $0.283^{*}$ & 0.061 & 110.5 \\
\hline ビタミン $\mathrm{B}_{12} \quad(\mu \mathrm{g})$ & $3.14 \pm 1.80$ & $4.37 \pm 4.01$ & 0.127 & 0.020 & 71.9 \\
\hline マグネシウム（mg） & $164 \pm 54$ & $154 \pm 43$ & $0.393^{* * *}$ & 0.118 & 106.9 \\
\hline 亜鉛（ $\mu \mathrm{g})$ & $5,320 \pm 1,739$ & $4,931 \pm 1,410$ & $0.483^{* * *}$ & 0.056 & 107.9 \\
\hline 銅（ $\mu \mathrm{g} ）$ & $770 \pm 265$ & $729 \pm 203$ & $0.408^{* * *}$ & 0.206 & 105.6 \\
\hline 脂肪酸絵量 $(\mathrm{g})$ & $34.3 \pm 13.6$ & $30.9 \pm 10.1$ & $0.251^{*}$ & 0.071 & 110.8 \\
\hline 飽和脂肪酸（g） & $10.9 \pm 4.5$ & $9.8 \pm 3.8$ & $0.274^{*}$ & 0.076 & 111.4 \\
\hline 一価不飽和脂肪酸（g） & $13.4 \pm 5.4$ & $12.3 \pm 4.7$ & 0.240 & 0.160 & 108.9 \\
\hline 多価不飽和脂肪酸（g） & $9.9 \pm 4.1$ & $8.8 \pm 2.8$ & $0.243^{*}$ & 0.039 & 112.8 \\
\hline n-6脂肪酸（g） & $8.1 \pm 3.3$ & $7.0 \pm 2.3$ & $0.260^{*}$ & 0.013 & 115.9 \\
\hline$n-3$ 脂肪酸（g） & $1.8 \pm 0.8$ & $1.8 \pm 0.7$ & 0.115 & 0.736 & 102.3 \\
\hline
\end{tabular}

注) ${ }^{*} p<0.05,{ }^{* *} p<0.01,{ }^{* * *} p<0.001$ 栄養素摄取量 $=$ 食品群ごとのポーションサイズ $(\mathrm{g}) \times$ 重量カテコリー\#×摂取回数 $/ 7 \times$ 荷重平均成分表の食品群 $100 \mathrm{~g}$ 当たり
の各栄養素量 $/ 100$

\#重量カテコリー別（「食べない」=0,「少し」=0.5,「普通」=1,「たっぷり」=1.5）の倍数をかける。重量カテゴリーの ない質問はこの項を省く。

茶飲料は除く。栄養補助食品は記録法による摄取がなかったため省いた。 
との比が 90 ～ $110 \%$ 範囲にあり, 全栄養素の平均の比 は104\%であった。エネルギー, たんぱく質, 脂質, 炭 水化物, ミネラル, ビタミンなど 26 種類の栄養素にお いて paired $t$-検定による有意差は認められなかった。 相関係数について 0.4 以上の值が得られた栄盖素は，工 ネルギー, たんぱく質, 炭水化物, カルシウム, ビタミ ン $\mathrm{B}_{1}$, ビタミン $\mathrm{B}_{2}$ など 13 種類であった。

調査対象が 19 歳学生と一般成人で年齢が大きく異な るため, 19 歳学生のみで相関係数を求めたところ, エ ネルギー0.55, たんぱく質 0.47 , 全員を対象とした相 関係数より高い值が得られた。これは学生が食物栄養専
攻という専門的知識を有した者であったためと考えられ る。

\section{FFQg法と記録法による食品群別掑取量の比較} 食品群別摂取量（表 5 ）の相関係数が高値であったの は, 米類 (0.66), パン類 (0.76), 牛乳 (0.72), その他 の乳製品 $(0.58)$, 果物 $(0.64)$, ジャム・ハチミッ類 (0.71), 菓子類（合計） (0.54), バター・マーガリン (0.67), 漬け物類 (0.61), 味噌 (0.68) で, 29食品群中 22 種類について有意な水準（ $p<0.05 ）$ が得られた。 FFQg 法の記録法に対する比においては, 肉・肉加工品 類, 大豆・大豆製品, その他の野菜・きのこ類, 菓子類,

表5 FFQg 法と記録法による食品群別搷取量（1日平均）の比較

\begin{tabular}{|c|c|c|c|c|c|}
\hline \multirow{2}{*}{ 食品群 } & FFQg 法 & 記録法 & \multirow{2}{*}{ 相関係数 } & \multirow{2}{*}{$\begin{array}{c}\text { paired } t \text {-検定 } \\
p \text { 値 (両側) }\end{array}$} & \multirow{2}{*}{$\begin{array}{c}\text { FFQg 法/ } \\
\text { 記録法(\%) }\end{array}$} \\
\hline & 平均値 $(\mathrm{g}) \pm$ 標準偏差 & 平均値 $(\mathrm{g}) \pm$ 標準偏差 & & & \\
\hline 米類 & $141.3 \pm 60.0$ & $126.8 \pm 50.2$ & $0.658^{* * *}$ & 0.014 & 111.4 \\
\hline パン類 & $31.9 \pm 26.4$ & $37.2 \pm 30.8$ & $0.761^{* * *}$ & 0.039 & 85.8 \\
\hline 麺類 & $20.6 \pm 18.4$ & $23.3 \pm 21.4$ & $0.479^{* * *}$ & 0.303 & 88.6 \\
\hline 肉 - 肉加工品類 & $75.1 \pm 47.7$ & $57.6 \pm 36.4$ & $0.270^{*}$ & 0.008 & 130.3 \\
\hline 魚介類 & $43.5 \pm 34.2$ & $46.7 \pm 30.0$ & $0.268^{*}$ & 0.501 & 93.0 \\
\hline 卵類 & $39.1 \pm 21.8$ & $41.1 \pm 18.8$ & $0.480^{* * *}$ & 0.444 & 95.2 \\
\hline 大豆・大豆製品（味噌は除く） & $44.7 \pm 37.4$ & $32.0 \pm 23.8$ & $0.434^{* * *}$ & 0.004 & 139.9 \\
\hline 牛乳 & $87.8 \pm 79.3$ & $77.7 \pm 80.9$ & $0.722^{* * *}$ & 0.179 & 113.0 \\
\hline その他の乳製品 & $21.7 \pm 24.9$ & $26.0 \pm 41.8$ & $0.580^{* * *}$ & 0.318 & 83.6 \\
\hline 海草類 & $1.3 \pm 1.0$ & $3.1 \pm 4.3$ & $0.300^{*}$ & 0.001 & 40.5 \\
\hline 小魚類 & $2.4 \pm 3.8$ & $2.8 \pm 5.8$ & 0.217 & 0.587 & 85.1 \\
\hline 緑黄色野菜 & $51.0 \pm 34.4$ & $48.0 \pm 26.2$ & $0.462^{* * *}$ & 0.448 & 106.3 \\
\hline その他の野菜·きのこ類 & $115.9 \pm 66.7$ & $81.6 \pm 38.3$ & $0.532^{* * *}$ & $<0.001$ & 142.1 \\
\hline 果物 & $64.8 \pm 65.3$ & $54.7 \pm 61.2$ & $0.635^{* * *}$ & 0.137 & 118.5 \\
\hline いも類 & $34.4 \pm 26.3$ & $37.5 \pm 28.9$ & $0.320^{* *}$ & 0.450 & 91.9 \\
\hline ジャム・八チミッ類 & $0.5 \pm 1.1$ & $0.4 \pm 1.3$ & $0.711^{* * *}$ & 0.668 & 111.3 \\
\hline 菓子類（合計） & $86.1 \pm 66.6$ & $43.1 \pm 48.9$ & $0.537^{* * *}$ & $<0.001$ & 199.8 \\
\hline 砂糖 & $5.9 \pm 4.4$ & $6.3 \pm 4.5$ & $0.404^{* * *}$ & 0.529 & 93.9 \\
\hline その他の嗜好飲料 a & $50.3 \pm 65.1$ & $57.4 \pm 72.5$ & $0.654^{* * *}$ & $<0.001$ & 87.7 \\
\hline アルコール類 & $6.2 \pm 22.3$ & $7.2 \pm 21.2$ & 0.070 & 0.788 & 86.1 \\
\hline 油脂類 & $6.0 \pm 4.4$ & $5.6 \pm 2.3$ & $0.321^{* *}$ & 0.414 & 108.7 \\
\hline マヨネーズ・ドレッシング類 & $4.8 \pm 2.9$ & $3.8 \pm 3.7$ & 0.211 & 0.044 & 125.4 \\
\hline バター・マーガリン & $1.0 \pm 1.3$ & $2.0 \pm 3.1$ & $0.669^{* * *}$ & $<0.001$ & 50.2 \\
\hline 種実類 & $0.9 \pm 2.8$ & $1.7 \pm 10.7$ & 0.227 & 0.539 & 54.2 \\
\hline 種実類（ゴマ） & $0.4 \pm 0.6$ & $0.4 \pm 0.7$ & 0.212 & 0.996 & 99.9 \\
\hline 梅干し・佃煮類 & $1.7 \pm 2.9$ & $0.6 \pm 1.1$ & 0.126 & 0.002 & 313.2 \\
\hline 漬け物類 & $9.1 \pm 15.3$ & $4.4 \pm 7.8$ & $0.613^{* * *}$ & 0.002 & 207.3 \\
\hline 調味料類（しょうゆ・ソース類） & $3.5 \pm 3.3$ & $14.7 \pm 7.8$ & 0.005 & $<0.001$ & 23.9 \\
\hline 味噌 & $7.8 \pm 4.5$ & $7.3 \pm 5.3$ & $0.680^{* * *}$ & 0.370 & 106.2 \\
\hline
\end{tabular}

注）、茶飲料は除く。栄養補助食品は記録法による捸取がなかったため省いた。 ${ }^{*} p<0.05,{ }^{* *} p<0.01,{ }^{* * *} p<0.001$ 米類は米, めん類および海草類は乾燥重量に換算した。 食品群別攝取量 $=$ 食品群ごとのポーションサイス $(\mathrm{g}) \times$ 重量カテコリー\#×摄取回数 $/ 7$ \#重量カテコリー別（「食べない」=0,「少し」=0.5, 「普通」=1,「たっぷり」=1.5）の倍数をかける。重量カテコリーの ない質問はこの項を省く。 
梅干し・佃者類, 漬け物類が大きかったが, 魚介類, 卵 類, 緑黄色野菜, いも類, 砂糖, 油脂類, 種実類 (ゴマ), 味噌については 90 1 10\%の範囲にあった。特に少なく 見積もられた食品群は海草類, バター・マーガリン, 種 実類, 調味料類（しょうゆ・ソース類）であった。

4. FFQg法に設定したポーションサイズと記録法に よる 1 回当たり推定捸取量の比較

記録法から推定された 1 回当たり摄取量と FFQg 法で 設定した重量カテゴリーごとの重量との差がェ $25 \%$ 以 内であった者の割合 (適正回答率) は, 15 食品群の平 均で $34 \%$ であった（表 6 )。海草類, いも類, 調味料類 （しょうゆ・ソース類）は適正回答率が低かった。一方, FFQg 法の重量カテゴリー「2．普通」を選択した人の 記録法での 1 回当たり推定捸取量（平均）と, FFQgの 基準ポーションサイズとの差がェ $25 \%$ 以内であった食 品群は, 15 食品群中, 肉 - 肉加工品類, 魚介類, 緑黄 色野菜, その他の野菜・きのこ類, 果物, いも類, 種実 類 (ゴマ) の 7 種類であった。
5. 味の感じ方によるファクターを用いた食塩摂取量 の比較

FFQg 法で質問した外食料理の味の感じ方により，力 テゴリー別に食塩摂取量の平均値を求めた。FFQg 法と 記録法での食塩搨取量の平均值は表 7 に示した。FFQg 法でファクターを乗じて補正した食塩摂取量と補正をし なかった食塩搨取量を，記録法による摂取量と比較する と,「1．家庭の味より外食の味を薄く感じる」と回答 した者の補正有りとの差は $0.39 \mathrm{~g}$, 補正なしとの差は $1.40 \mathrm{~g}$ であった。同様に「2，家庭と外食の味はほとん ど同じ」と回答した者では補正有り $0.04 \mathrm{~g}$, 補正なし $0.57 \mathrm{~g}$ で，両者ともファクターを用いて補正した方が記 録法との差が小さくなった。

\section{考察}

29 食品群と 10 種類の調理法に設定したポーションサ イズ（3カテゴリー）と，1 週間の摂取頻度の質問から， 日常の $1 \sim 2$ か月程度の食事における栄養素および食品

表6 FFQg法で重量カテゴリー「2. 普通」を選択した人の記録法での1回当たり推定摂取量（平均）と適正回答率

\begin{tabular}{|c|c|c|c|c|c|c|}
\hline \multirow{2}{*}{\multicolumn{2}{|c|}{ 食品群 a }} & \multirow[t]{2}{*}{$\begin{array}{l}\text { FFQg 回答 } \\
\text { 延べ人数 }\end{array}$} & \multirow[t]{2}{*}{$\begin{array}{c}\mathrm{FFQg} \text { で「2. 普通」 } \\
\text { を選択した人数 }\end{array}$} & \multirow[t]{2}{*}{$\begin{array}{l}\text { FFQgのポー } \\
\text { ションサイズ }(\mathrm{g})\end{array}$} & $\begin{array}{l}F F Q g \text { 法で「2. 普通」を } \\
\text { 選択した人の記録法の } \\
1 \text { 回当たり推定摄取量 } \\
\end{array}$ & \multirow[t]{2}{*}{$\begin{array}{c}\text { 適正回答率 } \mathrm{d} \\
(\%)\end{array}$} \\
\hline & & & & & 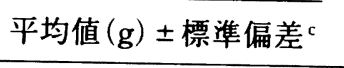 & \\
\hline \multirow{2}{*}{\multicolumn{2}{|c|}{$\begin{array}{l}\text { 肉・肉加工品類 } \\
\text { 魚介類 }\end{array}$}} & 198 & 96 & 80 & $61.2 \pm 52.7$ & 39.4 \\
\hline & -1 & 198 & 78 & 80 & $77.4 \pm 68.4$ & 37.9 \\
\hline \multicolumn{2}{|c|}{ 大豆・大豆製品 } & 198 & 66 & 70 & $40.3 \pm 41.6$ & 39.9 \\
\hline \multicolumn{2}{|c|}{ 海草類 } & 66 & 20 & 4 & $6.3 \pm 8.7$ & 18.2 \\
\hline \multicolumn{2}{|c|}{ 緑黄色野菜 } & 198 & 79 & 50 & $40.9 \pm 34.1$ & 36.9 \\
\hline \multirow{2}{*}{\multicolumn{2}{|c|}{$\begin{array}{l}\text { その他の野菜・きのこ類 } \\
\text { 果物 }\end{array}$}} & 198 & 88 & 80 & $63.4 \pm 39.3$ & 38.4 \\
\hline & & 66 & 22 & 150 & $131.7 \pm 106.2$ & 30.3 \\
\hline \multicolumn{2}{|c|}{ いも類 } & 66 & 39 & 100 & $89.2 \pm 72.7$ & 21.2 \\
\hline \multicolumn{2}{|c|}{ 砂糖（飲み物用） } & 66 & 15 & 6 & $0.8 \pm 2.2$ & 53.0 \\
\hline \multicolumn{2}{|c|}{ その他の嗜好飲料 } & 66 & 15 & $110,250,350$ & $436.1 \pm 516.8$ & 39.4 \\
\hline \multicolumn{2}{|c|}{ バター・マーガリン } & 66 & 19 & 4 & $7.4 \pm 4.7$ & 30.3 \\
\hline \multicolumn{2}{|c|}{ 種実類（ゴマ） } & 66 & 10 & 2 & $2.3 \pm 2.4$ & 30.3 \\
\hline \multirow{2}{*}{\multicolumn{2}{|c|}{$\begin{array}{l}\text { 梅干し・佃者類 } \\
\text { 漬け物 }\end{array}$}} & 66 & 10 & 10 & $3.3 \pm 3.7$ & 39.4 \\
\hline & & 66 & 20 & 30 & $13.3 \pm 13.7$ & 42.4 \\
\hline \multicolumn{2}{|c|}{ 調味料類（しょうゆ・ソース類） } & 66 & 32 & 7 & $28.8 \pm 31.5$ & 9.1 \\
\hline $\begin{array}{l}\text { 注) } \\
\text { a } \\
{ }^{\circ} \\
{ }^{\circ}\end{array}$ & 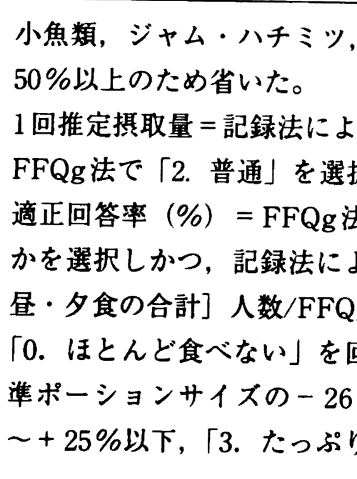 & $\begin{array}{l}\text {, 種実類, } \\
\text { よる1週間の: } \\
\text { 択した人の } \\
\text { 法で重量カラ } \\
\text { よる1回推定 } \\
\text { Qgの回答延- } \\
\text { 回答した者 } \\
6 \% \text { 以下, 「2 } \\
\text { りを回答し }\end{array}$ & 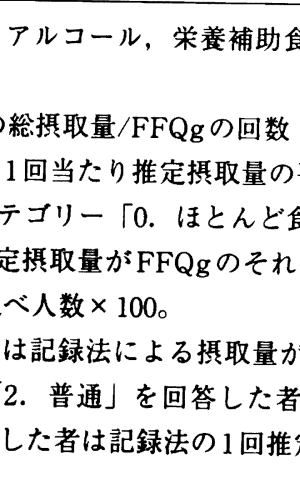 & 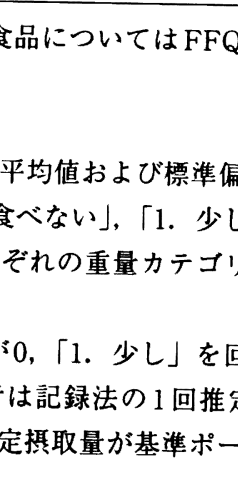 & $\begin{array}{l}\text { g法の回答で「0. ほとんど食 } \\
\text { 差を示す。 } \\
\text { J, 「2. 普通」,「3. たっぷり } \\
\text {-の設定重量 } \pm 25 \% \text { 以内'の } \\
\text { 答した者は記録法の1回推定 } \\
\text { E搨取量が基準ポーションサ } \\
\text { ションサイズの+ }+26 \% \text { サ上。 }\end{array}$ & $\begin{array}{l}\text { 」のいずれ } \\
\text { D延べ [朝・ } \\
\text { 摂取量が基 } \\
\text { イズの- } 25\end{array}$ \\
\hline
\end{tabular}


表 7 外食の味に対する感じ方による食塩摄取量（1日平均）

\begin{tabular}{|c|c|c|c|c|}
\hline \multirow[b]{2}{*}{ 外食の味の感じ方 } & \multirow[b]{2}{*}{ 人数 } & \multicolumn{2}{|c|}{ FFQg 法 } & \multirow{2}{*}{$\begin{array}{c}\text { 記録法 } \\
\text { 平均値 }(\mathrm{g}) \pm \text { 標準偏差 }\end{array}$} \\
\hline & & $\begin{array}{c}\text { ファクター有 } \\
\text { 平均値 }(\mathrm{g}) \pm \text { 土標準偏差 }\end{array}$ & $\begin{array}{c}\text { ファクター無 } \\
\text { 平均値 }(\mathrm{g}) \pm \text { 土標準偏差 }\end{array}$ & \\
\hline 1. 家庭の味より外食の味を薄く感じる & 6 & $8.04 \pm 1.96$ & $7.03 \pm 1.66$ & $8.43 \pm 2.32$ \\
\hline 2. 家庭と外食の味はほとんど同じ & 34 & $8.97 \pm 4.08$ & $8.44 \pm 3.84$ & $9.01 \pm 4.07$ \\
\hline 3. 家庭の味より外食の味を濃く感じる & 26 & $7.37 \pm 3.25$ & $7.37 \pm 3.25$ & $7.94 \pm 2.80$ \\
\hline
\end{tabular}

注） *FFQg法と記録法の paired $t$-検定の結果，FFQg 法ファクター有：記録法 $=0.549[p$ 值（西側 $)], F F Q g$ 法ファクター無： 記録法 $=0.163[p$ 值（両側 $) 〕$

群別搷取量を推定する食物摂取頻度調査票を開発し，そ の妥当性を検討した。ポーションサイズは，1997年に 実施された徳島県県民健康・栄養調査結果 ${ }^{16)}$ をとに 食品群ごとの 1 回当たりの摃取量を求め, これを $\mathrm{FFQg}$ 法のポーションサイズの普通量とした。また, FFQg法 に用いた栄養計算のための荷重平均成分表も県民健康 栄盖調查結果 ${ }^{16)}$ から作成した。FFQg 法では計算に使 用される食品成分表により, 計算結果が左右されるとこ ろであるが，エネルギーやたんぱく質など主要な栄養素 は平成 9 年国民栄盖調査結果から算出された食品群 $100 \mathrm{~g}$ 当たりの栄養素量の値に近く, 特定の地域に限定される 荷重平均成分表ではなかった。

比較調查として7日間の食事記録を実施した結果, FFQg 法によって推定された栄養素揸取量の平均値は記 録法による摄取量の $72 \sim 121 \%$ の範囲にあり，31 栄盖 素中 19 栄盖素は $10 \%$ 以内の差であった。さらに，相関 係数ではエネルギー, たんぱく質, 炭水化物, カルシウ ム, ビタミン $\mathrm{B}_{1}$, ビタミン $\mathrm{B}_{2}$, ビタミン $\mathrm{C}$ など 13 種類 の栄養素において 0.4 以上の相関が得られた。よって, FFQg 法で計算されたエネルギーおよび栄養素摂取量 は，記録法による食事状況をよく把握していたと判断で きる。

食品群別摄取量についての相関俰数は摄取頻度の少な かった小魚や種実類, 調味料類 (しょうゅ・ソース類) で低値であったが, 29 食品群中 22 食品群において有意 な相関 $(p<0.05)$ が認められた。しかし, 肉・肉加工品 類の相関係数は有意 $(p<0.05)$ であったものの, paired $t^{t}$-検定の結果は差がないとは言えなかった。肉・肉加工

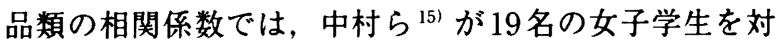
象に 7 日間の秤量記録法において比較した結果 0.47 , 城 田ら ${ }^{13)}$ が成人病健診受診者 65 名を対象に 1 週間の食事 記録と比較した結果 0.324 という值があるが, 我々の值 はこれらの結果より低い値 $(r=0.270)$ であった。これ は中村ら ${ }^{15)}$ の $40 \sim 150 \mathrm{~g}$ の 5区分, 城田ら ${ }^{13)}$ の男 $35 \sim$ $140 \mathrm{~g}$, 女30〜120 g とした重量区分に比べ，カテゴリ 一数や設定重量が異なることも一因と考えられる。 FFQg 法の回答時に食品群ごとのポーションサイズを
適切に判断（記録法による食品群別の 1 回当たり推定摄 取量がFFQg 法のポーションサイズ $25 \%$ 以内であっ た者を適正回答者とした）して選択した者の割合は， $「 0$ 。ほとんど食べない」と回答した割合が $50 \%$ 以上の 食品群を除いた 15 食品群の平均で $34 \%$ であった。 Guthrie $^{22)}$ による18～30歳の147人を対象にしたポーシ ョンサイズ推定の調查では, 実際の重量の $\pm 25 \%$ 以内 で重量を正しく回答した者は, ポーションサイズを推定 するための道具が無い場合では8～68\%の範囲であり， 平均すると $38 \%$ で，ポーションサイズの推定には回答 者に対して補助が必要であると述べている。我々の FFQg では食品群ごとに合計してポーションサイズを推 定する必要があるが，適正回答率はGuthrie ${ }^{22)}$ とほほ同 椂な結果となり, 肉・肉加工品類, 魚介類, 大豆 $\cdot$ 大豆 製品, 緑黄色野菜, その他の野菜・きのこ類, 砂糖（飲 み物用), その他の嗜好飲料, 梅干し・佃煮類, 漬け物 では比較的高い值が得られた。

一方, FFQg 法で「2. 普通」を回答した者の記録法 での 1 回当たり推定摄取量の平均が $\mathrm{FFQg}$ 法の基準ポー ションサイズの $\pm 25 \%$ 以内であった食品群は, 15 食品 群中 7 種類あった。適正回答率の比較的高い肉・肉加工 品類, 魚介類, 緑黄色野菜, その他の野菜・きのこ類, 果物, ゴマは上記の 1 回当たり推定摄取量も $25 \%$ 以内 の範囲にあり, ポーションサイズの推定がほほ適切であ ったと考えられた。しかし，FFQgで「2，普通」を選 択した者の割合が平均で $35 \%$ \%゙ったのに対して, 記 録法による 1 回当たり推定摂取量が $\mathrm{FFQg}$ の基準ポーシ ヨンサイズの $\pm 25 \%$ 以内の人数は $12 \%$ にしかすぎなか った。このことより，FFQgのカテゴリー選択が「2． 普通」に偏る傾向があることがわかった。そのため, 適 正回答率も低くなったと考えられる。また，本研究結果 を基に基準ポーションサイズを再検討することも必要と 考えられる。

FFQg 法で調理法についての頻度を質問することは食 塩や油脂類，砂糖など調味料として使用される食品の捸 取量推定に有効であった。今回の FFQg 法では食塩，砂 糖，油脂類については料理の回数から計算できるように 
考案した。さらに, 家庭によって異なる味の浱度を考虑 して，食塩の摄取量を推定するために，外食に対する味 の感じ方からファクターを乗じることにより計算できる ようにした。この方法により食塩摄取量は記録法の値に より近い值となり，補正は有効であったと考えられる。 食塩の 1 日平均掑取量は両調査法間で近い值となり, 食 塩の相関俰数においても $0.426(p<0.01)$ と, 中村 $5^{15)}$ の 0.31 の報告より高い值が得られた。調理に使用される 調味料は, 秤量記録法でも測定は難しく, 通常使用され る分量や調味パーセントで計算されることが多い。伊達 ら 9) は料理りストを使用した頻度調查法を利用し, 料 理を食品に分解する手間を省く方法を報告している。こ の方法では, 使用材料や調味料を知らない被調査者でも 回答が簡単な利便性があることを述べている。しかし， 調査にかかる時間が 40 分と我々の所要時間の約 2 倍で ある。

再現性については, 記録法を実施した前後にFFQg 法 を実施して検討したが, FFQg 1 回目と 2 回目の栄養素 撕取量の比は 19 栄養素中 16 種類において $90 \sim 110 \%$ の 範囲であり, 食品群別撕取量についても28食品群中 11 種類において 0.5 以上の高い相関が得られた。よって, $1 \sim 2$ か月程度の期間をおいた再現性は良好であり, 栄 盖素摄取量の推定は十分可能であると考えられる。

FFQg 法の実施は, 調査票を配布し，イラストに示さ れた分量を参考に回答するように説明をしたが，栄養素 摄取量の相関係数は学生のみでの值が高く，一般の対象 者を含めるとやや低下した。このことより，食物や栄盖 についてなじみの少ない一般の人々を対象にする場合に は, より一層ポーションサイズ推定のための補助, 例え ば, フードモデルを使用したり，日常の食生活状況を聞 き取りながら，对面式で回答させるなどの工夫が必要と 考えられる。

FFQg 法に使用したイラストの表示も有効な手段であ る。今回使用したイラストは質問紙のスペースの関係か ら例示食品が限られるため, 示された食品のみについて 回答しかねないという懸念があったが, 例示食品の説明 を加えることによってそのような問題は避けられた。し かし, 果物など季節変動の大きいものについては, 季節 により例示内容を変更することも必要であると思われ る。また, これからの食環境を予測すると, 例示として 調理済み加工品も取り入れる必要があるだろう。100種 類以上におよぶ食品や料理に限定した食物摂取頻度調査 票は, 生活样式や食生活の変化が激しい現代では, 新規 食品や多種多様な料理に対応してフードリストを更新す るのが困難であるが, 食品群を利用した FFQgはある程 度, 既存の食品群に例示食品を追加することで対応でき る長所がある。
以上，食品群をべースにして，さらに調理法による調 味料の計算方法を取り入れた食物摄取頻度調查票 （FFQg）は, 個人の栄養素や食品群別摄取量の特徵を 推定することができることが判明した。これらの結果を 生かし，この質問票によるコンピューターシステムを充 実させ, 日常の食事揸取状況の把握への利便性を高めて いきたい。我々はこのシステムを広く提供したいと考え ている。

\section{ま と め}

個人の過去 $1 \sim 2$ 只間における平均的な 1 日の栄盖 素提取量を推定することを目的として，食品群をベース にした食物攝取頻度調查票（FFQg）（29の食品群と 10 の料理の質問から構成）を作成し，19～60歳の 66 名を 対象として，7 日間食事記録法と比較し，その妥当性を 検討した。

1） FFQg 法と記録法によるエネルギーおよび栄盖 素摄取量の相関倸数はエネルギー 0.47 , たんぱく質 0.42 , 脂質 0.39 , 炭水化物 0.49 , カルシウム 0.41 であった。 FFQg 法によるエネルギーと栄養素摃取量の記録法に対 する比は平均で $104 \%$ であり， $72 \%$ （ビタミン B 12 ） か ら $121 \%$ (ビタミンC) の範囲にあった。

2 ) 両調査法間の食品群別摄取量の相関係数では, 米類 0.66 , パン類 0.76 , 肉 - 内加工品類 0.27 , 魚介類 0.27 , 牛乳 0.72 , 乳製品 0.58 , 緑黄色野菜 0.46 , その他 の野菜・きのこ類 0.53 , 果物 0.64 となり, 29 食品群中 22 食品群については有意な相関が得られた $(p<0.05)$ 。

3 ） FFQgの重量カテゴリー（ポーションサイズ） を正しく推定して選択された割合は，「0．ほとんど食 べない」と回答した割合が $50 \%$ 以上の食品群を除いた 15 食品群の平均で $34 \%$ あ゙あた。また, FFQgで「2． 普通」を選択した者の割合が平均で $35 \%$ であったのに 対して, 記録法による 1 回当たり推定摄取量（記録法に よる 1 週間の総摄取量/FFQg 法で回答された回数) が $\mathrm{FFQg}$ の基準ポーションサイズの $\pm 25 \%$ 以内の人数は $12 \%$ あったことより, FFQgのカテゴリー選択が「2． 普通」に偏る傾向がみられた。

4）食塩の摂取量の推定において, 外食に対する味 の感じ方からファクターを乗じることにより, 食塩搨取 量は記録法の值により近い值となった。

以上の結果, 正しくポーションサイズを認識して，カ テゴリーを選択するには何らかの補助が必要と考えられ たが，食品群をべースに作成した食物摄取頻度調查票 （FFQg）を用いた個人のエネルギーおよび栄養素捸取 量を推定する方法は，栄養素だけでなく，食品群別摄取 量や食塩摄取量の推定において妥当性が認められ，有効 な手段である。 
文献

1) Willett, W. : Nutritional Epidemiology (1989)

/田中平三監訳：食事調查のすべて一栄盖疫学一, pp.80-147（1996）第一出版，東京

2) Burke, B.S. : The dietary history as a tool in research, J. Am. Diet. Assoc., 23, 1041-1046 (1947)

3) Mullen, B.J., Krantzler, N.J., Grivetti, L.E., Schutz, H.G. and Meiselman, H.L. : Validity of a food frequency questionnaire for the determination of individual food intake, Am. J. Clin. Nutr., 39, 136-143 (1984)

4) Flegal, K.M., Larkin, F.A., Metzner, H.L., Thompson, F.E. and Guire, K.E. : Counting calories : Partitioning energy intake estimates from a food frequency questionnaire, Am. J. Epidemiol., 128, 749760 (1988)

5) Romieu, I., Stampfer, M.J., Stryker, W.S., Hernandez, M., Kaplan, L., Sober, A., Rosner, B. and Willett, W.C. : Food predictors of plasma Betacarotene and Alpha-tocopherol : Validation of a food frequency questionnaire, Am. J. Epidemiol., 131, 864876 (1990)

6) Briefel, R.R., Flegal, K.M., Winn, D.M., Loria, C.M.. Johnson, C.L. and Sempos, C.T. : Assessing the nation's diet : Limitations of the food frequency questionnaire, J. Am. Diet. Assoc., 92, 959-962 (1992)

7) Jain, M., Howe, G.R., Johnson, K.C. and Miller, A.B. : Evaluation of a diet history questionnaire for epidemiologic studies, Am. J. Epidemiol., 111, 212219 (1980)

8）古野純典, 内岡三枝子, 武若秀子, 徳留裕子, 石松成子, 吉村健清：がん研究における食事調査法の検 討，癌の臨床，36，409-415（1990）

9）伊達ちぐさ, 福井 充, 島田豊治, 藤井千鶴子, 柳 元和, 白田久美子, 門奈丈之, 吉池信男, 岩谷昌子, 松村康弘, 杉山みちこ, 山口百子, 中山健夫, 横山徹爾, 陳 浩, 清野富久江, 岩岡浩子, M.M. Zaman, 下里
誠, 田中平三：新しい食物攝取頻度調查法の確立をめ ざして一再現性と妥当性の検討一, 厚生の指標, 42,22 -29 (1995)

10）森本絢美，高瀨幸子，秦 鸿四，細谷憲政：簡 易食物提取調査による栄養素量の測定, 栄養学雑誌, 35 , 235-245（1977）

11）健康の指標策定検討会：健康の指標策定検討会 報告書, pp.10-26（1981）

12）早㴊仁美, 井上厚美, 池田雅人：簡易食生活実 態調査法の一試案 I 調査票, 福岡女子大学家政学部紀 要, 17, 41-50 (1985)

13）城田知子, 吉住笑美子：簡易食物摄取量調查法 の検討，日本公衛誌，37，100-108（1990）

14）伊藤和枝，益田敦子，上園慶子，川崎晃一：簡 易法による栄養素等摄取量推定方法の検討, 日本栄養・ 食糧学会誌，45，535-543（1992）

15）中村美詠子，青木伸雄，那須恵子，近藤今子： 食品撖取頻度 ・摄取量法と 7 日間秤量記録法の比較, 日 本公衛誌，41，682-691（1994）

16）徳島県：県民健康・栄養の現状（平成 9 年県民 健康・栄養調査結果）（1998）

17）藤井美希, 坂井文代, 森夏菜子, 高橋啓子, 吉村 幸雄，山内圭子，坂井堅太郎，筒井実知代，大塚優子, 山本茂：穴吹町農業従事者の栄養調査, 阿波学会紀要, 45, 127-137 (1999)

18）香川 綾：四訂食品成分表 1996, pp.497-502 （1996）女子栄養大学出版部, 東京

19）吉村幸雄，高橋啓子：エクセル栄盖君 Plus Ver2.1（1998）建帛社, 東京

20）香川劳子監修：会社別 - 製品別市販加工食品成 分表（1995）女子栄盖大学出版部, 東京

21) SPSS 9.0 J for Windows Professional Statistics （1997）エス・ピー・エス・エス，東京

22) Guthrie, H. A. : Selection and quantification of typical food portions by young adults, J. Am. Diet. Assoc., 84, 1440-1444 (1984)

(受付：平成 12 年 7 月 27 日, 受理 : 平成 13 年 6 月 16 日) 